\title{
SHRIMP U-Pb zircon geochronology of volcanic rocks hosting world-class Be-U-Li-F mineralization, Spor Mountain, Utah, U.S.A.
}

\author{
ROBERT AYUSO ${ }^{* 1}$ NORA FOLEY ${ }^{1}$ AND JORGE VAZQUEZ ${ }^{2}$ \\ ${ }^{1}$ U.S Geol. Surv., Reston, VA, USA, (*correspondence: \\ nfoley@usgs.gov, rayuso@usgs.gov) \\ ${ }^{2}$ U.S Geol. Surv., Menlo Park, CA, USA \\ (jvazquez@usgs.gov)
}

We report U-Pb zircon data establishing the age of the Spor Mountain Formation [1], a volcanic sequence that hosts the largest deposit of beryllium (Be) in the world. Determining the age of rocks hosting the deposit is critical for improved recognition of exploration targets containing additional volcanic-hosted $\mathrm{Be}$ resources. The deposit occurs in an area of extensive alkalic rhyolitic ash flow tuffs and Oligocene and Eocene calderas underlain by Paleozoic and older limestone, dolomite, shale, and quartzite. We show that lower fluorite and bertrandite-rich tuff and upper topaz-rich rhyolite have overlapping crystallization ages. Zircon from the crystal- and lithic-rich Be tuff produced a predominant group yielding a weighted average ${ }^{206} \mathrm{~Pb} /{ }^{238} \mathrm{U}$ age of crystallization of 25.59 $+0.29 /-0.45 \mathrm{Ma}$ and a separate younger age group at 20.84 $+1.29 /-0.64 \mathrm{Ma}$ (reflecting $\mathrm{Pb}$ loss from thermal events related to renewed influx of hydrothermal F-rich fluids). There is no evidence for older or inherited cores. Zircon from the rhyolite yields a weighted mean ${ }^{206} \mathrm{~Pb} /{ }^{238} \mathrm{U}$ crystallization age of $25.4+0.54 /-1.48 \mathrm{Ma}$. Temperatures of crystallization based on Ti contents in zircon from tuff range from $\sim 600{ }^{\circ} \mathrm{C}$ to $1200{ }^{\circ} \mathrm{C}$ and in rhyolite from $\sim 525{ }^{\circ} \mathrm{C}$ to $1000{ }^{\circ} \mathrm{C}$. Mass fractions of $\mathrm{Be}$ in zircon from tuff and rhyolite overlap $(\sim 1$ to $150 \mathrm{ppm})$ and do not correlate with U-Pb spot age, $\mathrm{Hf}, \mathrm{Ti}$, and other trace element abundances or ratios. REE contents of zircon (chondrite-normalized) are depleted in light REE, enriched in heavy REE, and show prominent positive Ce and negative Eu anomalies. V-shaped REE patterns characterize zircons younger than ca. 25.6 Ma. Zircons from both tuff and rhyolite have $\mathrm{Th} / \mathrm{U}$ values typical of igneous zircon, plot in the field of continental settings, and are consistent with an origin from sources relatively enriched in $\mathrm{Pb}$. The Spor Mountain Formation reflects the interplay of alkaline (Atype) trachytic to rhyolitic magma enriched in $\mathrm{Be}, \mathrm{U}, \mathrm{Li}$, and $\mathrm{F}$ and a protracted history of fractional crystallization overprinted by late dueteric to hydrothermal alteration.

[1] Ayuso et al., 2020, J. Geochem. Explor. 109 1-22. 